\title{
PENINGKATAN PENGETAHUAN MANAJEMEN KOPERASI SYARIAH PADA PENGURUS DAN ANGGOTA RINTISAN KOPERASI SYARIAH BERKAH KABUPATEN BANDUNG BARAT
}

\author{
Bambang Wisnuadhi ${ }^{1}$, Setiawan ${ }^{2}$, Ghifari Munawar ${ }^{1}$, Dimas Sumitra Danisworo ${ }^{2}$, Hasbi \\ Assidiki Mauluddi $^{2}$ \\ ${ }^{1}$ Jurusan Teknik Komputer dan Informatika, Politeknik Negeri Bandung \\ ${ }^{2}$ Jurusan Akuntansi Politeknik Negeri Bandung \\ Email: bwisnuadhi@ polban.ac.id
}

\begin{abstract}
Abstrak
Koperasi di Indonesia memiliki tujuan untuk dapat meningkatkan taraf hidup masyarakat khusunya anggota koperasi. Namun, masih banyak koperasi tidak bisa berkembang bahkan berhenti beroperasi karena banyaknya persoalan yang dihadapi. Rintisan Koperasi Syariah Berkah (KSB) merupakan salah satu rintisan koperasi di desa Tanimulya Kec. Ngamprah Kab. Bandung Barat yang sedang banyak menghadapi persoalan yaitu kurangnya pengetahuan para pengurus dan anggota mengenai konsep dasar dan manajemen koperasi syariah. Melihat kondisi ini, Tim PKM Polban memandang perlu untuk memberikan pelatihan dalam peningkatan pengetahuan mengenai manajemen koperasi syariah kepada KSB. Melalui pemberdayaan ini diharapkan Rintisan KSB dapat menjadi koperasi yang dapat mensejahterakan anggotanya. Pemberdayaan KSB dilakukan melalui pemberian pelatihan konsep dasar koperasi dan manajemen koperasi syariah, serta perbaikan administrasi koperasi syariah. Metode yang digunakan yaitu penyampaian materi manajemen koperasi syariah kemudian dilakukan pendampingan untuk memastikan materi yang disampaikan dapat diaplikasikan. Dari kegiatan PKM, peserta mendapat banyak pengetahuan baru mengenai manajemen koperasi syariah. Sedangkan hasil kuesioner yang disebarkan pada peserta diperoleh tingkat kepuasan yang tinggi terhadap kegiatan PKM yang telah dilangsungkan. Selain itu, peserta juga berharap ada kegiatan lanjutan pada tahun depan yaitu manajemen usaha dan strategi bisnis untuk koperasi syariah, manajemen keuangan, manajemen pemasaran, serta perancangan aplikasi untuk koperasi syariah.
\end{abstract}

Kata kunci: Koperasi Syariah, Peningkatan Pengetahuan, Konsep Dasar Koperasi Syariah, Manajemen Koperasi Syariah 
DIFUSI

Volume 3, No.2 Juli 2020

\section{PENDAHULUAN}

Koperasi merupakan soko guru perekonomian Indonesia yang keberadaan dan eksistensinya dijamin oleh undang-undang [1]. Keberadaan koperasi di Indonesia memiliki tujuan untuk dapat mensejahterakan masyarakat. Telah banyak program yang dibuat oleh pemerintah untuk mengatasi kemiskinan namun hasilnya belum signifikan sehingga diperlukan instrumen yang tepat untuk menangani kemiskinan [2]. Contoh program yang masih eksis adalah Kartu Keluarga Sejahtera (KKS) yang belum bisa membuat masyarakat kurang mampu untuk lebih produktif.

Koperasi dapat meningkatkan taraf hidup masyarakat khusunya anggota koperasi yang bersangkutan. Koperasi menempatkan anggota sebagai unsur penting dalam organisasi. Semakin besar anggota koperasi semakin menunjukkan bahwa koperasi tersebut direspon dengan baik oleh pelanggan yang menjadi anggota [3].

Untuk dapat terus berkembang dibutuhkan para pengelola dan sumber daya manusia yang kompeten dan terampil di bidangnya [4]. Oleh sebab itu sumber daya manusia yang ada di dalamnya perlu dibekali pengetahuan dan keterampilan tentang perkoperasian yang memadai. Dalam kongres International Cooperative Alliance (ICA) tahun 1966 yang ditegaskan bahwa setiap organisasi koperasi wajib melaksanakan pelatihan dan Pendidikan perkoperasian untuk menyebarluaskan ide dan praktik baik koperasi, yang meliputi aspek perusahaannya dan aspek demokrasinya [4]. Hal ini berlaku bagi seluruh koperasi yang ada di Indonesia.

Kabupaten Bandung Barat memiliki jumlah koperasi yang cukup banyak, yaitu sekitar 873 [5]. Memiliki potensi yang cukup baik untuk bisa memberdayakan masyarakatnya melalui koperasi. Salah satunya adalah Rintisan Koperasi Syariah Berkah yang telah diinisiasi semenjak November 2017. Rintisan Koperasi Syariah Berkah beroperasi di wilayah Komplek Puri Cipageran Indah 2, RW 21, Desa Ngamprah, Kec. Tanimulya, Kabupaten Bandung Barat. Adapun data warga RW disajikan dalam Tabel 1 .

Tabel 1. Demografi Warga RW 21 Desa Tanimulya Kecamatan NgamprahKabupaten Bandung Barat Menurut Kepercayan

\begin{tabular}{ccrrrrrr}
\hline \multirow{2}{*}{ No } & \multirow{2}{*}{ RT } & \multicolumn{2}{c}{ Muslim } & \multicolumn{2}{c}{ Non Muslim } & \multicolumn{2}{c}{ Jumlah } \\
\cline { 3 - 8 } & & KK & \multicolumn{1}{c}{ Jiwa } & \multicolumn{1}{c}{ KK } & Jiwa & \multicolumn{1}{c}{ KK } & \multicolumn{1}{c}{ Jiwa } \\
\hline 1 & RT 01 & 82 & 317 & 10 & 33 & 92 & 350 \\
2 & RT 02 & 46 & 193 & 8 & 32 & 54 & 225 \\
3 & RT 03 & 72 & 281 & 7 & 20 & 79 & 301 \\
4 & RT 04 & 42 & 172 & 4 & 15 & 46 & 187 \\
5 & RT 05 & 44 & 167 & 3 & 14 & 47 & 181 \\
6 & RT 06 & 33 & 130 & 5 & 22 & 38 & 152 \\
\hline & Jumlah & $\mathbf{3 1 9}$ & $\mathbf{1 . 2 6 0}$ & $\mathbf{3 7}$ & $\mathbf{1 3 6}$ & $\mathbf{3 5 6}$ & $\mathbf{1 . 3 9 6}$ \\
\hline
\end{tabular}

Sumber: Sekretaris RW 21 Desa Tanimulya 
DIFUSI

Volume 3, No.2 Juli 2020

Sampai akhir 2018, jumlah anggota Rintisan Koperasi Syariah Berkah berjumlah 36 orang. Sedangkan pengurus koperasi berjumlah 8 orang yang menjabat pengawas, ketua, sekretaris, bendahara, bagian pembelian, dan bagian penjualan. Latar belakang dari pengurus sangat beragam mengingat keberadaan koperasi ini berkat semangat untuk menggerakkan ekonomi masyarakat. Bisnis yang sudah berjalan baru meliputi penjualan produk makanan dan bahan pokok. Selain itu ada pula produk sesuai pesanan masayarakat.

Namun sampai saat ini, koperasi tersebut masih belum berbadan hukum sehingga belum diakui secara legal. Koperasi dapat eksis hingga kini berkat loyalitas anggotanya. Permasalahan paling mendasar untuk dapat berbadan hukum adalah belum baiknya manajemen pengelolaan perkoperasian terutama dalam hal pencatatan keuangan. Lebih jauh perlu diberikan pelatihan dan pendampingan yang melibatkan pengurus agar pengetahuan dan keterampilan pengelolaan koperasi syariah dapat memadai.

Pelatihan dan pendampingan terhadap Rintisan Koperasi Syariah Berkah dilaksanakan dalam Program Pengabdian kepada Masyarakat yang bersumber dari dana UPPM Polban. Kegiatan ini sangat dibutuhkan Rintisan Koperasi Syariah Berkah dan dapat berkontribusi besar dalam mengembangkan perekonomian di lingkungan Desa Tanimulya. Secara umum, keberadaan BMT diterima dengan baik oleh masyarakat dan berpotensi untuk berkembang di segmen Usaha Mikro Kecil dan Menengah (UMKM) [6].
Oleh karena keterbatasan dana, waktu, dan tenaga, maka kegiatan Program Pengabdian kepada Masyarakat ini dibatasi hanya untuk pengelolaan manajemen perkoperasian serta kemampuan dasar pendukung lainnya.

\section{METODE}

Ada 2 (dua) kegiatan utama yang dilakukan dalam pelaksanaan program ini, diantaranya yaitu:

\section{Program Penyampaian Materi}

Program ini dilaksanakan selama 2 kali tatap muka, dengan melibatkan sekitar 30 orang peserta. Program pelatihan ini dilaksanakan di Masjid Al Hikmah Desa Tanimulya Kec. Ngamprah Kabupaten Bandung Barat yang merupakan tempat yang biasa digunakan para pengurus dan anggota berkumpul dan melakukan pengajian rutin. Pada kesempatan ini akan disampaikan materi mengenai konsep dasar koperasi syariah dan manajemen koperasi syariah.

\section{Program pendampingan}

Setelah pelatihan dilaksanakan, maka program selanjutnya adalah pendampingan bagi pengelola Rintisan Koperasi Syariah Berkah. Pendampingan tersebut ditujukan untuk memandu pengelola Rintisan Koperasi Syariah Berkah dalam menerapkan materi pelatihan sebelumnya agar dapat diimplementasikan dengan baik.

Kegiatan Pengabdian Kepada Masyarakat ini dilakukan dengan cara pemberian materi mengenai konsep dasar dan ma- 
DIFUSI

Volume 3, No.2 Juli 2020

najemen Koperasi Syariah pada pengurus dan anggota Rintisan Koperasi Syariah Berkah serta pada masyarakat yang tergabung dalam Majelis Ta'lim $\mathrm{Mu}-$ tiara Hikmah di Masjid Al Hikmah Desa Tanimulya Kec. Ngamprah Kabupa- ten Bandung Barat. Seperti diketahui bahwa Rintisan Koperasi Syariah Berkah hadir berkat kesadaran dan tekad para aktivis masjid Al-Hikmah. Kegiatan berlangsung selama 2 kali pertemuan.

Tabel 2. Susunan Tim Pengusul dan Pembagian Tugas

\begin{tabular}{|c|c|c|c|}
\hline NO. & NAMA & JABATAN & TUGAS \\
\hline 1. & $\begin{array}{l}\text { Bambang Wisnuadhi, } \\
\text { S.Si., MT. }\end{array}$ & $\begin{array}{l}\text { Ketua } \\
\text { PKM/ } \\
\text { Dosen D4- } \\
\text { Teknik } \\
\text { Informatika }\end{array}$ & $\begin{array}{l}\text { 1. Memimpin tim kerja program pengabdian } \\
\text { kepada masyarakat. } \\
\text { 2. Komunikasi dan koordinasi dengan mitra } \\
\text { PKM. } \\
\text { 3. Memberikan materi persiapan untuk } \\
\text { pembentukan Koperasi Syariah berbadan hukum. } \\
\text { 4. Mendampingi persiapan untuk } \\
\text { pembentukan Koperasi Syariah berbadan hukum. }\end{array}$ \\
\hline 2. & $\begin{array}{l}\text { Setiawan, SE., } \\
\text { ME.Sy. }\end{array}$ & $\begin{array}{l}\text { Anggota/ } \\
\text { Dosen D4- } \\
\text { Keuangan } \\
\text { Syariah }\end{array}$ & $\begin{array}{l}\text { 1. Membuat proposal PKM } \\
\text { 2. Menyusun materi kegiatan. } \\
\text { 3. Membuat laporan akhir PKM. } \\
\text { 4. Membuat draft artikel untuk publikasi } \\
\text { ilmiah }\end{array}$ \\
\hline 3. & $\begin{array}{l}\text { Ghifari Munawar, } \\
\text { S.Kom., MT. }\end{array}$ & $\begin{array}{l}\text { Anggota/ } \\
\text { Dosen D4- } \\
\text { Teknik } \\
\text { Informatika }\end{array}$ & $\begin{array}{l}\text { 1. Survei lapangan. } \\
\text { 2. Membuat konsep pelaksanaan kegiatan di } \\
\text { lapangan. } \\
\text { 3. Melatih pengadminsitrasian dan tata kelola } \\
\text { bagi pengurus. } \\
\text { 4. Mendampingi pelaksanaan administrasi dan } \\
\text { tata kelola mitra. }\end{array}$ \\
\hline 4. & $\begin{array}{l}\text { Dimas Sumitra } \\
\text { Danisworo, SST., } \\
\text { M.Sc. }\end{array}$ & $\begin{array}{l}\text { Anggota/ } \\
\text { Dosen D4- } \\
\text { Keuangan } \\
\text { Syariah }\end{array}$ & $\begin{array}{l}\text { 1. } \text { Mengelola anggaran pendanaan } \\
\text { 2. Mengatur pengadministrasian kegiatan. } \\
\text { 3. Mendokumentasikan kegiatan. } \\
\text { 4. } \\
\end{array}$ \\
\hline 5. & $\begin{array}{l}\text { Hasbi Assidiki, } \\
\text { SE.Sy., ME.Sy. }\end{array}$ & $\begin{array}{l}\text { Anggota/ } \\
\text { Dosen D4- } \\
\text { Keuangan } \\
\text { Syariah }\end{array}$ & $\begin{array}{l}\text { 1. Menginventarisir kebutuhan kegiatan } \\
\text { 2. Memberikan materi konsep dasar koperasi } \\
\text { syariah dan manajemen koperasi syariah. } \\
\text { 3. Mengolah data. } \\
\text { 4. Mendampingi konsep dasar koperasi } \\
\text { syariah. }\end{array}$ \\
\hline
\end{tabular}

Dalam pelaksanaan PKM ini, tim dari POLBAN yang terdiri dari 5 orang personel dosen telah mendapat pendanaan dari DIPA POLBAN. Agar pelaksanaan
PKM dapat berjalan sesuai perencanaan, maka tim yang dipimpin oleh Bambang Wisnuadhi ini melakukan pembagian tugas seperti terlihat pada Tabel 2 . 
DIFUSI

Volume 3, No.2 Juli 2020

Pada saat pelaksanaan, jumlah peserta pada pertemuan pertama sebanyak 20 orang dan pada pertemuan kedua sebanyak 29 orang. Kegiatan PKM dilakukan sesuai jadwal rutin pengajian. Sehingga untuk selanjutnya, diharapkan materi semacam ini dapat disampaikan oleh pemateri yang biasa mengisi kajian di Masjid Al Hikmah. Pemilihan waktu ini juga dapat memudahkan sasaran kegiatan dengan tidak melakukan penjadwalan khusus.

Penyajian materi menggunakan aplikasi presentasi dan proyektor untuk mempermudah visualisasi ilustrasi dan contoh dari konsep ataupun kasus pada koperasi syariah. Selain itu, peserta kegiatan pun dibekali dengan materi yang telah dibuat modul berbentuk hardcopy. Agar peserta bisa membuka materi tersebut di kala dibutuhkan.

Materi disampaikan melalui ceramah dan tanya jawab. Peserta diberi kesempatan bertanya di pertengahan ceramah sehingga lebih fleksible dan keingin tahuannya bisa langsung terjawab. Antusiasme peserta cukup tinggi. Ini terlihat dari banyaknya pertanyaan yang diajukan kepada. Peserta mendapatkan pengetahuan baru mengenai konsep dasar koperasi syariah dan manajemen koperasi syariah. Sebelumnya mereka belum pernah mendapatkan materi sejenis, baik dari ceramah pada majelis taklim ataupun dari kegiatan lain.

\section{HASIL DAN PEMBAHASAN}

Pada pertemuan pertama, materi yang diberikan kepada anggota dan pengurus
KSB adalah persiapan untuk pembentukan Koperasi Syariah berbadan hukum. Terdapat beberapa hal yang harus dipersiapkan oleh KSB. Walaupun sebagian telah ada namun belum dilengkapi secara administratif. Berikut beberapa hal yang harus disiapkan adalah (1) Persyaratan pembentukan Koperasi Syariah, yaitu: (a) Minimal 20 orang untuk keanggotaan; (b) Wilayah kedudukan berada di Republik Indonesia; (c) Modal sendiri yang berasal dari anggota; (d) Disiapkan nama koperasi yang disepakati; dan (e) Apa jenis usaha yang akan dijalankan.

Dengan syarat yang terpenuhi, selanjutnya pihak perintis koperasi mengajukan rencana pembentukan ke dinas koperasi setempat. Maka dinas koperasi akan memberikan pembekalan pengetahuan dasar-dasar perkoperasian. Setelah mendapat pembekalan, koperasi melakukan rapat pembentukan yang dihadiri: calon pendiri (pemilik modal awal), undangan dari pusat atau dinas koperasi, serta notaris. Hasil dari pertemuan tersebut dibuatkan berita acara pembentukan (bila sampai terwujud mufakat untuk pembentukan koperasi) yang kemudian dijadikan dasar sebagai dasar pembuatan akta notaris.

Kemudian dinas koperasi verifikasi atas semua kelengkapan syarat pendirian koperasi, termasuk: (a) validitas pendiri; (b) domisili koperasi; ketersediaan modal awal; dan (d) penggunaan nama yang belum digunakan oleh koperasi lain. Tahapan ini disertai dengan pendaftaran badan hukum koperasi oleh notaris serta persetujuan anggaran dasar koperasi koperasi. Bila disetujui, maka akan diterbitkan Surat Keputusan badan hukum koperasi. 
DIFUSI

Volume 3, No.2 Juli 2020

Selain materi persiapan untuk pembentukan badan hukum, diberikan pula materi mengenai pengenalan tata kelola dan pengadministrasian dalam operasional koperasi syariah. Berikut buku administrasi yang wajib dimiliki oleh koperasi (termasuk koperasi syariah): Buku Daftar Anggota; Buku Daftar Pengu- rus; Buku Daftar Badan Pengawas; Buku Daftar Manager; Buku Daftar Simpanan; Buku Notulen Rapat; Buku Notulen Rapat Pengurus; Buku Notulen Rapat Badan Pengawas; Buku Catatan Kejadian; Buku Anjuran Pejabat Koperasi; Buku Anjuran Pejabat lain; Buku saran Anggota; Buku Tamu; Buku Inventaris; dan Buku Agenda.

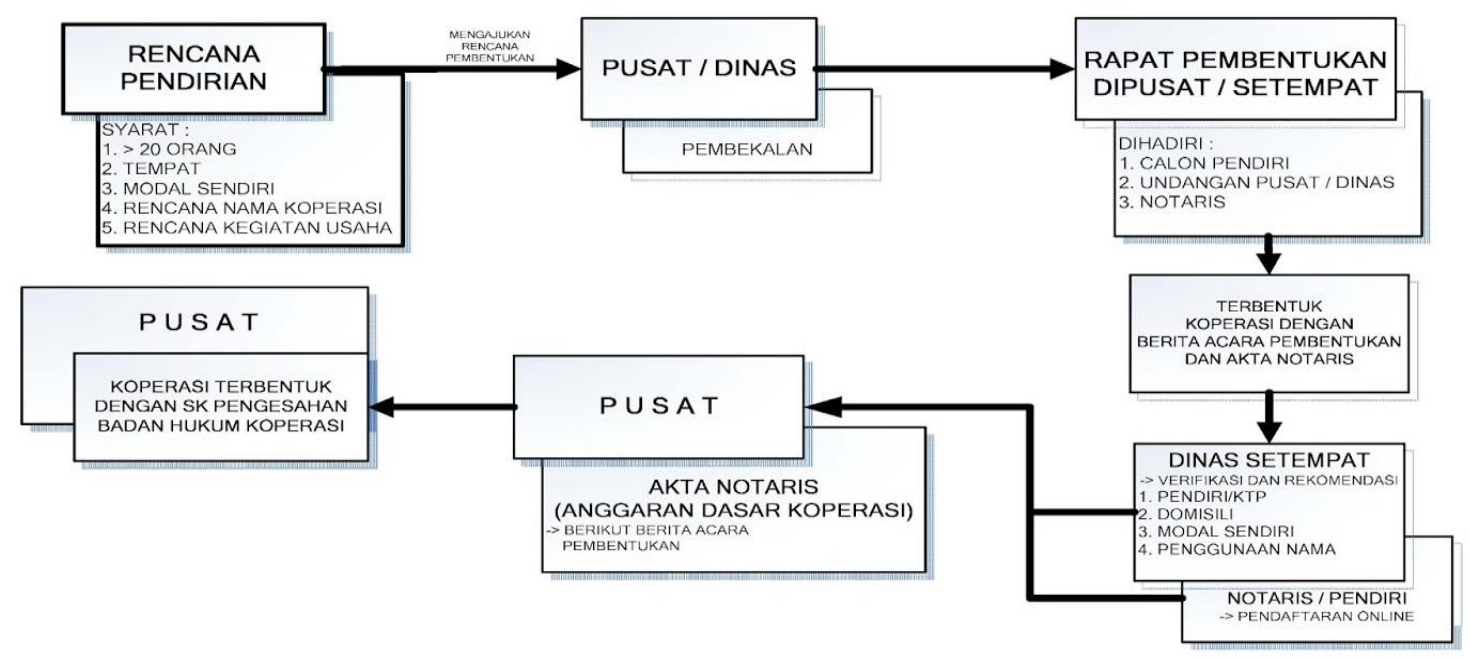

Gambar 1. Skema Proses Pembentukan Koperasi

Pada pertemuan kedua, materi yang disampaikan lebih menekankan pada aspek manajemen koperasi syariah. Materi yang diberikan hanya berfolus pada Manajemen Kelembagaan. Hal ini sebagai penguat materi yang telah disampaikan pada pertemuan pertama dan juga sebagai bekal persiapan koperasi syariah berbadan hukum. Materi ini meliputi: (a) standar organisasi dan manajemen koperasi syariah; (b) standar pengelolaan organisasi; (c) standar pengelolaan unit usaha; (d) standar penutupan unit $\mathrm{u}$ saha serta pembubaran koperasi syariah; (e) standar penggunaan dan pembagian Sisa Hasil Usaha (SHU); (f) standar penggunaan dan pengelolaan harta kekayaan koperasi syariah; dan (g) ketentuan peralihan.
Dengan pemahaman baru yang telah disampaikan, maka peserta memiliki pemahaman yang cukup untuk bisa meningkatkan kinerja kioperasi syariah menjadi lebih baik dan berjalan sesuai dengan norma dan nilai-nilai syariah. Selain itu, koperasi syariah lebih siap untuk melakukan pembentukan koperasi syariah berbadan hukum.

Sebagai bahan evaluasi kegiatan, maka dilaksanakan pengisian kuesioner untuk melihat dampak serta seberapa besar manfaat yang diberikan dari kegiatan PKM. Selain itu, dilakukan pula wawancara kepada peserta bersangkutan mengenai materi yang disampaikan, yaitu apakah materi sejenis pernah mereka 
DIFUSI

Volume 3, No.2 Juli 2020

dapat atau tidak. Seluruh peserta mengakui telah mendapatkan materi baru yang belum mereka ketahui tentang koperasi syariah. Hal ini menjadi bukti bahwa tujuan kegiatan PKM ini terlak- sana, yaitu peningkatan pengetahuan pengetahuan manajemen koperasi syariah pada pengurus dan anggota rintisan KSB.

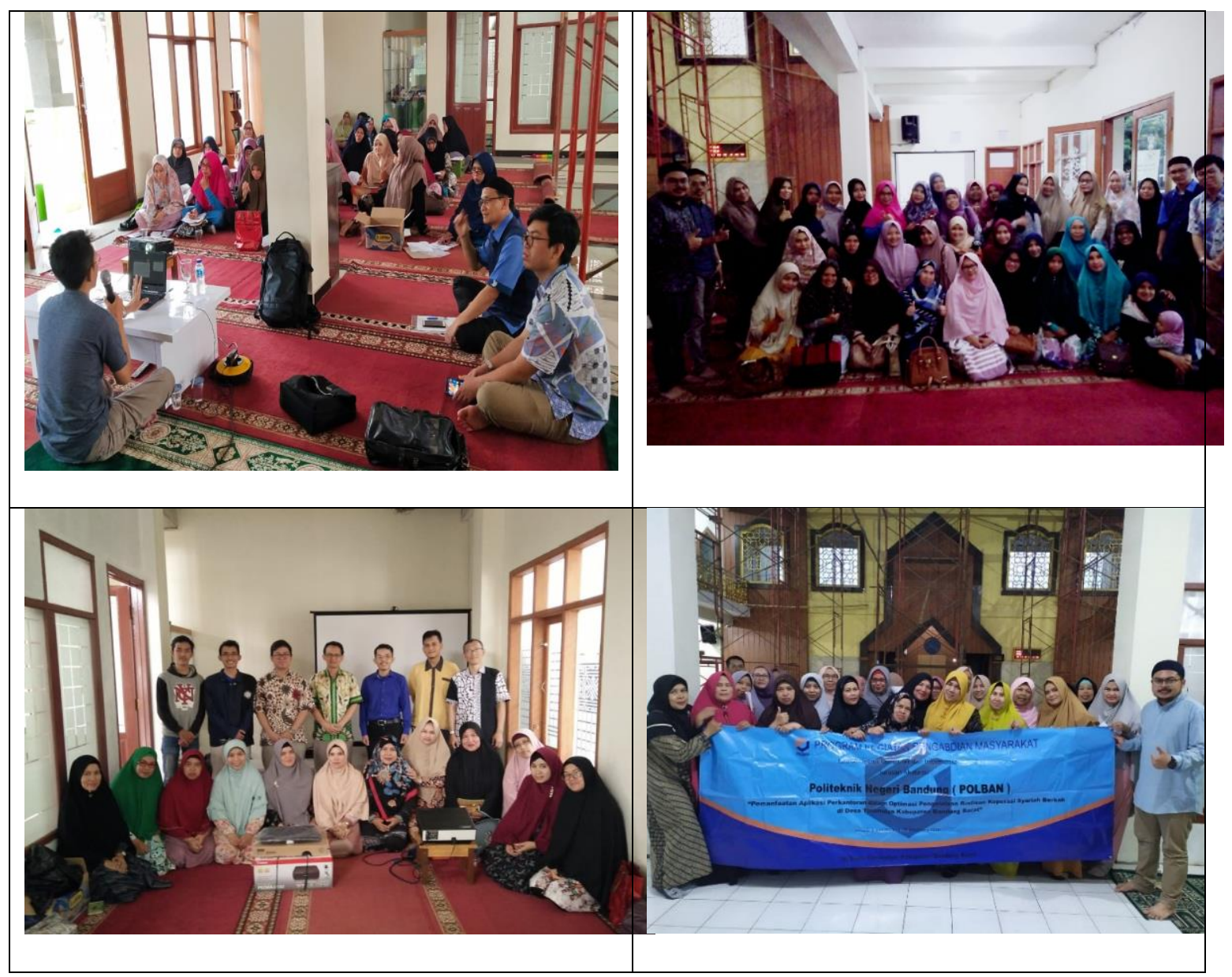

Gambar 2. Pengurus dan Anggota Koperasi Syariah Berkah Kabupaten Bandung

Sedangkan pengisian kuesioner dilakukan secara independen dan tanpa menyertakan identitas pengisi agar peserta dapat menilai secara objektif. Aspek yang diukur meliputi: tingkat kepuasan peserta terhadap kegiatan PKM yang diselenggarakan, kesesuaian materi PKM dengan kebutuhan peserta, tingkat kepuasan layanan personil terhadap peserta, kemampuan narasumber dalam memberikan solusi terhadap masalah yang disampaikan peserta dan minat partisipasi dalam kegiatan PKM berikutnya.

Berdasarkan rekapitulasi hasil pengisian kuesioner pada Tabel 3 di atas, dapat dilihat bahwa rata-rata peserta puas dengan kegiatan PKM yang diadakan. Nilai rata-rata tertinggi yang dicapai ada- 
DIFUSI

Volume 3, No.2 Juli 2020

lah tingkat kepuasaan dari kegiatan yang sesuai dengan harapan para peserta dengan capaian 4,83 . Secara umum skor rata-rata adalah 4,53 artinya mitra dan peserta pelatihan merasakan manfaat dan kepuasan yang tinggi dari kegiatan pengabdian kepada masyarakat ini.

Tabel 3. Rekapitulasi Hasil Evaluasi Kegiatan

\begin{tabular}{|c|c|c|}
\hline No. & PERNYATAAN & Rata-rata \\
\hline 1. & $\begin{array}{l}\text { Saya merasa puas dengan kegiatan pengabdian masyarakat yang } \\
\text { diselenggarakan. }\end{array}$ & 4,67 \\
\hline 2. & $\begin{array}{l}\text { Kegiatan pengabdian masyarakat yang diselenggarakan tim POLBAN } \\
\text { sesuai dengan harapan saya. }\end{array}$ & 4,83 \\
\hline 3. & $\begin{array}{l}\text { Personil/anggota yang terlibat dalam kegiatan pengabdian masyarakat } \\
\text { memberikan pelayanan sesuai dengan kebutuhan saya. }\end{array}$ & 4,50 \\
\hline 4. & $\begin{array}{l}\text { Setiap keluhan/pertanyaan/permasalahan yang saya ajukan ditindaklanjuti } \\
\text { dengan baik oleh narasumber/anggota yang terlibat }\end{array}$ & 4,50 \\
\hline 5. & $\begin{array}{l}\text { Jika kegiatan ini diselenggarakan kembali, saya bersedia untuk } \\
\text { berpartisipasi/terlibat }\end{array}$ & 4,17 \\
\hline \multicolumn{2}{|c|}{ Rata-rata Keseluruhan } & 4,53 \\
\hline \multicolumn{3}{|c|}{ Keterangan: sangat tidak setuju $=1$, tidak setuju $=2$, netral $=3$, setuju $=4$, sangat setuju $=5$} \\
\hline
\end{tabular}

\section{KESIMPULAN}

Kegiatan Pengabdian Kepada Masyarakat $(\mathrm{PkM})$ oleh tim POLBAN dapat berlangsung dengan lancar sesuai target yaitu meningkatkan pengetahuan manajemen koperasi syariah pada pengurus dan anggota rintisan KSB. Mitra yang bekerjasama dengan tim dari POLBAN yaitu Rintisan Koperasi Syariah Berkah merasa puas dengan kegiatan ini dan mengharapkan kegiatan dapat berlanjut di waktu yang akan datang. Materi yang diharapkan diperoleh pengurus maupun anggota KSB diantaranya manajemen usaha dan strategi bisnis untuk koperasi syariah, manajemen keuangan, manajemen pemasaran, serta perancangan aplikasi untuk koperasi syariah.
Berdasarkan evaluasi kegiatan yang telah dilaksanakan, terdapat beberapa saran untuk bisa ditindaklanjuti di antaranya:

a. Mengingat kegiatan PKM ini sangat bermanfaat maka hendaknya kegiatan serupa terus dilaksanakan pada tahun berikutnya. Kegiatan dapat dilakukan dengan melibatkan peserta yang lebih banyak dan jangkauan yang lebih luas seperti masyarakat yang belum menjadi anggota. Agar mereka dapat tertarik untuk menjadi anggota atau bahkan dapat berperan aktif dalam kegiatan koperasi syariah.

b. Mengingat kebutuhan mitra yang cukup kompleks maka tim dari POLBAN diharapkan berasal dari latar belakang yang berbeda agar 
bisa mengakomodir kebutuhan mitra.

\section{REFERENSI}

[1] S. Zulhartati, "Peranan Koperasi dalam Perekonomian Indonesia," Guru Membangun, 25(3), 2010.

[2] R. E. Wright, "Standardized poverty measurement," Journal of Economic Studies, pp.3-17, 1996.

[3] S. Sijabat, dan I. Idris, "Evaluasi Kelayakan Koperasi Menjadi Koperasi Skala Besar," Jurnal Pengkajian Koperasi dan UKM, 7, pp. $54-82,2012$.

[4] A. Heryati dan F. Afriyani, "Pelatihan Pembukuan dan Manajemen Koperasi bagi Pengurus Koperasi SMPN 26 Kota Palembang," Jurnal Abdimas Mandiri, 1(1), pp. 41-45, 2017.

[5] BPS, "Jumlah Koperasi, KUD dan Non KUD Menurut Kabupaten/Kota di Jawa Barat," 2018, (BPS) Dipetik Jan 30, 2019, dari https://jabar.bps.go.id/statictable/2018/04/03 1532/jumlah-koperasi-kud-dan-nonkud-menurut-kabupaten-kota-dijawa-barat-2018.html

[6] A. Rahman dan S. Desmaryani, "Kinierja, Daya Tarik, dan Keputusan Nasabah pada Baitul Mal Wat Tamwil di Provinsi Jambi. Walisongo." Jurnal Penelitian Sosial Keagamaan, 24(1), 57-78, Mei 2016.

[7] E. A. Iman, D. H. Setyowati, dan S. Setiawan, "Penurunan Persentase Kemiskinan Sebagai Dampak Kinerja Keuangan Organisasi Pengelola Zakat di Indonesia," Prosiding Industrial Research Workshop and National Seminar, Vol. 9, pp. 728736, Oktober 2018.

[8] Rudy, "Prosedure Pembentukan Koperasi dan Pengesahan Badan Hukum Sesuai Permen Koperasi No. 10 Tahun 2015," http://disperindagkop.tarakankota.go.id/egov/K operasi-UMKM/Berita-KoperasiUMKM/prosedure-pembentukankoperasi-dan-pengesahan-badanhukum-sesuai-permen-koperasi-no10-tahun-2015-640, 2016, www. umkmgodigital.biz, 2019. 